\title{
BUILDING OF ENTREPRENEURIAL ETHOS THROUGH MISSION STATEMENTS: THE DIFFERENCE IN APPROACH BETWEEN PUBLIC AND PRIVATE UNIVERSITIES IN THE CZECH REPUBLIC
}

\author{
Karel PERNICA ${ }^{2}$, Ladislav TYLL ${ }^{3}$
}

\begin{abstract}
Corporate mission statement is an essential statement to all stakeholders of the organization about its own purpose, its goals and the competitive advantage it offers to its customers. Another purpose of the mission is to create a so-called positive ethos. Universities represent a specific group of institutions from the perspective of defining missions and working with ethos. This paper identifies the elementary components of university missions that help build a positive ethos. The research is focused on the analysis of mission statements of all public and private universities operating in the Czech Republic. The results of this research show that there is a difference in the approach to defining missions between public and private universities (in terms of the inclusion of individual components that help building a positive ethos).
\end{abstract}

\section{KEY WORDS}

Content analysis, Ethos, Mission, Mission statement components

\section{JEL CLASSIFICATION}

L26, L25, I23, I25.

\section{INTRODUCTION}

Mission statements have been representing very valuable strategic tool for last forty years. The importance of their communication is integrated into virtually all activities. Starting with strategic planning, followed by manufacturing, marketing, public relations, personnel management and employee motivation, social responsibility and many others. Mission statement is considered to be a perfect basic building block for the company's strategic management process (David, 1984; Staples and Black, 1984). Recently, in addition, they have an important role when building a positive corporate ethos. In the given context, there is a question how universities, representing the highest level of education and bearers of the progress, work with this statement. To answer this question, there are two goals of this paper. (1) Firstly, identification of mission statements components contributing to a positive ethos building and (2) second, finding out whether there is a different

\footnotetext{
${ }^{2}$ Ing. Karel Pernica, Ph.D. student at University of Economics, Prague, Faculty of Business administration

${ }^{3}$ Ing. Ladislav Tyll, MBA., Ph.D., assistant professor at University of Economics, Prague, Faculty of Business administration
} 
approach to building a positive ethos using mission statements between public and private universities (in terms of contained components).

Every mission should be as unique as possible. Several guidelines have been introduced over years about which key components should be included. They vary in numbers or names; however, the content is still more or less the same. In this respect, one of the most often cited author is Fred. R. David (2011) and his nine components approach. According to David, company should provide information about the following nine components: customers; products and services; markets; technology; concern for survival, growth and profitability; corporate philosophy; self-concept; concern for public image; and concerns for employees.

Mission statement is most effective when it is approximately 100 words in length and when it avoids inclusion of monetary amounts, numbers, percentages, ratios of objectives. (David and Davis, 2003, Davies and Glaister, 1997, Kemp and Dwyer, 2003) Well designed mission should also create an emotional bond between company and its employees or customers. (Campbell and Yeung, 1991).

\section{Content of the mission statement}

Mission statement of a university should in general integrate all three following components: education, research and kind of public service (Scott, 2006). These components should define not only the structure of the institution and its expected educational and research deliverables but they should also represent a guideline for measuring organizational efficiency. Further, they should also contribute to building the positive identity of the university (Fugazzotto, 2009), thus to its positive ethos. Jongbloed, Enders and Salerno (2008) consider the university mission statement as a reflection of how the institution sees its contribution to society. In this regard, the authors suggest answering the following questions when defining a mission:

- What do we do? - What should we do?

- Who are our students? Who should be our students?

- What is the environment we operate in like? What are the opportunities?

- What are our resources? How should we redistribute our assets?

\section{Mission statement and organizational ethos}

Relating to the corporate mission statement there has been so far rarely used the term corporate ethos. The way the company wants to be perceived was expressed rather as an image (external ethos) or identity (an internal ethos). The theoretical basis for understanding the concept of ethos and the reason why it is indispensable for all speakers who want to be convincing is the rhetoric. Cross (1991) sees persuasiveness as a certain ability to win over audiences and inspire action, which should be the primary goal for all corporate messages, no matter whether the company wants to build a positive image or maintain a good reputation. If the company fails to persuade its stakeholders to trigger a desired action (such as stock purchases, increased employee performance, commitment, public perceptions of the environment), then any attempt to create a mission is useless (Williams, 2008).

Aristotle used the term "ethos" in his Rhetoric, where he described the techniques of convincing speech and presentation that have remained up to date. It is true that Aristotle was aiming his findings primarily on individuals, not on groups, let alone businesses. However, if someone wants to gain admiration and favor of the audience, it is completely irrelevant whether they are individuals or groups, the rules are still the same. In the first part of the book, ethos is one of the principles of persuasion, the other two are logos (rational reasoning) and pathos (emotions and passion) (Williams, 2008). Aristoteles considered the ethos as the most important. It consists of three parts: 
intelligence, character and goodwill, and it means some recognition by the listener in terms of the credibility of the speaker (Cooper, 1960).

\section{Intelligence}

Aristotle puts emphasis on intelligence (knowledge, common sense and expertise), which is a major contributor to credibility. If listeners for any reason doubt the speaker's knowledge, they can hardly take it seriously. Therefore, Aristoteles provides several strategies for formulating arguments to influence listeners. Swales and Rodgers (1995), however, due to the nature of the missions, do not see the implementation of these strategies as realistic. Nevertheless, if the organization provides in its mission accurate information on its products and services, management capabilities and procedures used to gain competitive advantage, thus the organization according to Stoddard (1984) demonstrates a certain amount of expertise. Moreover, a well-formulated mission is also an evidence of certain organization's knowledge and skills (Williams, 2008).

\section{Character}

Speaking about the second aspect of ethos, character, Aristotle claims that the speaker should prove the right character. In order to do so, he must know the differences between virtues and vices, and be aware of the qualities that are valued by the listener and society (Beason, 1991). Thus, If the organization presents values important to both society and stakeholders in its strategic mission statement, it will strengthen its ethos (Williams, 2008). When formulating the mission, the organization should carefully consider the values and beliefs that are important to it, because they could not only reinforce its ethos but if defined wrongly (wake and insincere) they could also seriously damage it (Collins and Porras, 2008).

Building of the right character through various statements of the organization influences countless factors. The authors must take into account the characteristics of the stakeholders, the purpose of each message, the context of the environment in which it operates, etc. (Stoddard, 1984). For example, public interest in corporate social responsibility and ethics is still increasing.

It seems to be also effective to emphasize the elements which are common for both the organization as well as for its stakeholders. When the speaker pops out of similarity, it will give the audience the impression that he is "one of them". It is therefore obvious, that people tend to trust someone who shares certain values and goals with them (Williams, 2008). Thus, when formulating mission statement, the word "we" (or any other pronoun in the first person of the plural) should not be omitted. So, the reader gets the feeling that he/she is a member of a particular group (Beason, 1991). For example, internal stakeholders (employees) identify themselves easier with the organization. Another reason to use the first person in the plural can be a simple demonstration of the team spirit and the cohesion of an organization that is externally presented as "we".

\section{Goodwill}

With regard to the third aspect of the ethos, Aristotle argues that the speaker should present himself as a man of goodwill with good intentions. If he/she can manage to create this image of him(her)self, he/she may expect good will also from the audience. Such behavior is mainly associated with altruism. Organizations must prove their unselfish way of thinking and act indiscriminately in favor and benefit of others (Shanahan a Seele, 2015). In order to satisfy the reader, it is essential to recognize his/her needs (emotional) and then to project them into the corporate mission. Different emotions are primarily build due to unmet needs (Williams, 2008).

\section{University mission statement ethos}

In order to evaluate and compare missions' ethos of Czech public and private universities, it is necessary to determine the individual components of missions involved in building a positive ethos. For the purpose of this paper they were defined as follows: 
Intelligence: 1) Education (product, service); 2) Research; 3) International impact.

Character: 4) Philosophy (values and believes); 5) Social responsibility (interest in public image).

Goodwill: 6) Public service; 7) Is the mission formulated using the pronoun "we".

Through the first three components, the university demonstrates its expertise. The pure character then through its values and interest in social responsibility. Goodwill and some altruism states through the components "public service" and the use of pronoun "we" in the mission. In regards the above mentioned there remains the question, whether there is a different approach to building positive ethos throughout mission statements (in terms of the use of above mentioned components) between public and private universities. Thus, we formulated the zero hypothesis.

H0: There is not a different approach to use individual components in their mission statements between public and private universities in the Czech Republic.

\section{Methodology}

The research includes all public, state and private higher education institutions in the Czech Republic that are allowed to provide higher education in its territory. Their list can be found on the website of the Ministry of Education, Youth and Sports of the Czech Republic. Their mission statements were subsequently searched firstly on universities websites and then in the documents available on these websites. Of these, there was first analyzed the document entitled "The Longterm Plan of the University for the Years 2016-2020", followed by annual reports. It should be noted that in some cases the mission published on the websites differed from the mission in the long-term plan document. Since the goal of this paper is to evaluate the building of ethos, there was always preferred a mission that was better accessible to website visitor.

The scoring of individual components of the missions was carried out using a two-point scale. If the mission contained the full component, it was awarded two points. If the mission contained the component only partially, it gained one point. If the mission did not include the component at all, no point was assigned to it. Scoring is based on the subjective evaluation of the authors of the paper.

The H0 hypothesis was tested in SPSS Statistics program using a two-tier Student's t-test, where there is an assumption of identical variance of tested variable in compared sample sets. That is, the final rating of individual missions based on used components.

\section{Results}

The research set comprised 69 universities, out of which 26 were public, 2 state-owned (analyzed together with public) and 41 private ones. From the perspective of explicitly declared and publish organizational mission statement public universities showed significantly better results compared to private ones. $96 \%$ of public universities formulated their missions compared to $73 \%$ of private universities. The bellow mentioned table displays number of searched missions.

\section{Table 1 Overview of analysed universities - mission statements}

\begin{tabular}{lll} 
& $\begin{array}{l}\text { Mission } \\
\text { Yes }\end{array}$ & No \\
\hline Public universities & $27(96 \%)$ & $1(4 \%)$ \\
\hline Private universities & $30(73 \%)$ & $11(27 \%)$ \\
\hline
\end{tabular}

It should be noted that in certain cases universities have included mission components in their strategic vision. Consequently, the resulting assessment in missions can be noticeably lower. 
However, the focus of the research was only on the missions of universities. In the table below, the numbers of visions are also presented.

Table 2 Overview of analysed universities - mission statements and visions

\begin{tabular}{|c|c|c|c|c|c|}
\hline & $\begin{array}{l}\text { Mission } \\
\text { vision }\end{array}$ & and & $\begin{array}{l}\text { Only } \\
\text { mission }\end{array}$ & Only vision & $\begin{array}{l}\text { No } \\
\text { statements }\end{array}$ \\
\hline Public universities & $25(89 \%)$ & & $2(7 \%)$ & $1(4 \%)$ & $0(0 \%)$ \\
\hline $\begin{array}{l}\text { Private } \\
\text { universities }\end{array}$ & $25(61 \%)$ & & $5(12 \%)$ & $1(2 \%)$ & $10(24 \%)$ \\
\hline
\end{tabular}

\section{University mission ethos}

In the first twenty universities, only 6 private universities are ranked according to the rankings of missions based on the components that reflect the positive ethos of universities. There is only 1 private university in the Top10 universities.

\section{Table 3 Universities with mission statements with strongest ethos}

\begin{tabular}{llllllllll}
\hline & \multicolumn{3}{l}{ Components } & & & & \\
\cline { 2 - 8 } & Type & 1 & 2 & 3 & 4 & 5 & 6 & 7 & $\Sigma$ \\
\hline $\begin{array}{l}\text { Palacky University in Olomouc (UP) } \\
\text { Janáček Academy of Music and Performing Arts in Brno } \\
\text { (JAMU) }\end{array}$ & public & 2 & 2 & 2 & 2 & 2 & 2 & 2 & 14 \\
University of Ostrava (OU) & public & 2 & 2 & 2 & 2 & 2 & 2 & 0 & 12 \\
University of Economics, Prague (VSE) & & & & & & & \\
University of Chemistry and Technology & 2 & 2 & 2 & 2 & 2 & 2 & 0 & 12 \\
(VSCHT) Prague & public & 2 & 2 & 2 & 2 & 2 & 2 & 0 & 12 \\
Academy of Performing Arts in Prague (AMU) & public & 2 & 2 & 2 & 2 & 1 & 2 & 0 & 11 \\
Academy of Fine Arts in Prague (AVU) & & & & & & & & & \\
University of Pardubice (UPa) & public & 2 & 2 & 2 & 1 & 1 & 2 & 0 & 10 \\
Moravian University College Olomouc, o.p.s. & public & 2 & 0 & 0 & 2 & 2 & 2 & 2 & 10 \\
Technical University in Liberec (TUL) & private & 2 & 2 & 2 & 2 & 1 & 2 & 0 & 10 \\
& public & 2 & 2 & 2 & 0 & 1 & 2 & 0 & 9 \\
\hline
\end{tabular}

As an example, we may use the mission statement of the university with the strongest ethos:

Palacky University in Olomouc

The mission of the University is to promote the involvement of students in all areas of research, to cultivate their critical and creative thinking, and to provide high-quality university education in a broad range of natural, medical, and social sciences and humanities on the Bachelor's, Master's, and Doctoral levels. Our active partnership with both the regional community and the global community contributes to the development of the intellectual wealth of the society and its sustainable scientific, technological, cultural, and social development.

In all that we do at Palacký University, we strive for perfection, innovation, engagement, team work, transparency, academic integrity, freedom and autonomy, necessary continuity, and integration into the society. We proudly acknowledge the rich and successful history of the university since 1573. We will continue to do our utmost to preserve and care for these values, maintaining and developing them. 
Palacký University Olomouc will continue to be a leading research-oriented university with the ambition to place among the top 5 Czech universities and the top 500 universities the world over.

At the opposite end of the ranking, the situation is diametrically different. There are only 5 public universities among the twenty universities with missions with the weakest ethos. The following table lists ten universities with missions with the weakest ethos.

\section{Table 4 Universities with mission statements with weakest ethos}

\begin{tabular}{llllllllll}
\hline & Components & & & & \\
& Type & 1 & 2 & 3 & 4 & 5 & 6 & 7 & $\Sigma$ \\
\hline Masaryk University (MU) & public & 1 & 0 & 0 & 0 & 0 & 2 & 0 & 3 \\
Mendel University in Brno (MENDELU) & public & 1 & 0 & 0 & 0 & 0 & 2 & 0 & 3 \\
The Institute of Technology and Business in Ceske & public & 0 & 0 & 1 & 1 & 0 & 1 & 0 & 3 \\
Budejovice & & & & & & & & & \\
STING Academy, o.p.s. - Brno & private & 1 & 0 & 0 & 0 & 0 & 2 & 0 & 3 \\
College of Business and Hotel Management & private & 1 & 0 & 1 & 0 & 1 & 0 & 0 & 3 \\
The College of Physical Education and Sport PALESTRA & private & 2 & 0 & 0 & 0 & 0 & 1 & 0 & 3 \\
Ltd. & & & & & & & & & \\
Film Academy of Miroslav Ondricek in Pisek, o.p.s. & private & 2 & 0 & 0 & 0 & 0 & 0 & 0 & 2 \\
University of Finance and Administration, a.s. & private & 1 & 1 & 0 & 0 & 0 & 0 & 0 & 2 \\
Karel Englis College in Brno, a.s. & private & 1 & 0 & 0 & 0 & 0 & 1 & 0 & 2 \\
College of Entrepreneurship and Law - Prague, a.s. & private & 2 & 0 & 0 & 0 & 0 & 0 & 0 & 2 \\
(VSPP) & & & & & & & & \\
\hline
\end{tabular}

There follows an example of the college with the weakest ethos:

College of Entrepreneurship and Law - Prague, a.s.

VSPP is a joint-stock company, which carries out its key processes in the form of education in accredited study programs and in compliance with the Higher Education Act and its own Statute. It creates conditions for the continuity of education focused primarily on entrepreneurship, which is the main mission of the school. As part of the strategic change, it seeks to achieve synergies that will lead to a shared goal and values sharing.

It is not surprising that the university's missions most frequently referred to education (Component 1, 54 occurrences) - see Table 5. With greater frequency, universities also saw their operations as a form of public service (No. 6; 49 occurrences). Only in four cases the university formulated its mission in the first-person plural "we". These were 3 public and 1 private university. Significant differences between public and private schools are only observed for the "research" (No. 2) and "social responsibility" components (No. 5) that are more commonly used by public universities.

Table 5 Individual components use in mission statements.

\begin{tabular}{llllllll}
\hline & \multicolumn{9}{c}{ Components } & & & \\
\cline { 2 - 8 } & 1 & 2 & 3 & 4 & 5 & 6 & 7 \\
\hline Total number of occurrences & 54 & 35 & 33 & 23 & 20 & 49 & 4 \\
\hline Public universities & 25 & 25 & 17 & 13 & 14 & 24 & 3 \\
Private universities & 29 & 16 & 16 & 13 & 6 & 25 & 1 \\
\hline
\end{tabular}

\section{Hypothesis testing in SPSS Statistics}


HO: There is not a different approach to use individual components in their mission statements between public and private universities in the Czech Republic.

\section{Table 6 Outcome from SPSS Statistics 1}

\section{Group Statistics}

\begin{tabular}{|l|l|l|l|l|l|}
\hline & University & $\mathrm{N}$ & Mean & $\begin{array}{l}\text { Std. } \\
\text { Deviation }\end{array}$ & $\begin{array}{l}\text { Std. Error } \\
\text { Mean }\end{array}$ \\
\hline Ethos score & $\begin{array}{l}\text { public } \\
\text { privat }\end{array}$ & 27 & 7,48 & 3,155 &, 607 \\
& 30 & 5,37 & 2,220 &, 405 \\
\hline
\end{tabular}

Table 7 Outcome from SPSS Statistics 2

\section{Independent Samples Test}

\begin{tabular}{|c|c|c|c|c|c|c|c|c|c|c|}
\hline \multirow{3}{*}{\multicolumn{2}{|c|}{ (2) - }} & \multicolumn{2}{|c|}{$\begin{array}{l}\text { Levene's } \\
\text { Test for } \\
\text { Equality of } \\
\text { Variances }\end{array}$} & \multicolumn{7}{|c|}{ t-test for Equality of Means } \\
\hline & & \multirow[t]{2}{*}{$\mathrm{F}$} & \multirow[t]{2}{*}{ Sig. } & \multirow[t]{2}{*}{$\mathrm{t}$} & \multirow[t]{2}{*}{ df } & \multirow[t]{2}{*}{\begin{tabular}{|l} 
Sig. \\
$(2-$ \\
tailed $)$
\end{tabular}} & \multirow[t]{2}{*}{$\begin{array}{l}\text { Mean } \\
\text { Difference }\end{array}$} & \multirow[t]{2}{*}{$\begin{array}{l}\text { Std. Error } \\
\text { Difference }\end{array}$} & \multicolumn{2}{|c|}{$\begin{array}{l}95 \% \\
\text { Confidence } \\
\text { Interval of the } \\
\text { Difference } \\
\end{array}$} \\
\hline & & & & & & & & & Lower & Upper \\
\hline $\begin{array}{l}\text { Ethos } \\
\text { score }\end{array}$ & $\begin{array}{l}\text { Equal } \\
\text { variances } \\
\text { assumed } \\
\text { Equal } \\
\text { variances } \\
\text { not } \\
\text { assumed }\end{array}$ & 5,354 &, 024 & $\begin{array}{l}2,950 \\
2,897\end{array}$ & 46,131 & ,005 & 2,115 & ,717 & $\begin{array}{l}, 678 \\
, 646\end{array}$ & $\begin{array}{l}3,552 \\
3,584\end{array}$ \\
\hline
\end{tabular}

By comparing the p-value of the test (Sig 2-tailed), namely 0.005 , with the chosen significance level $\alpha=0.05$, we find that the $p$-value is lower than the chosen level of significance, thus we reject the zero hypothesis and accept the alternative hypothesis.

H1: The approach to use individual components in their mission statements between public and private universities in the Czech Republic is statistically significantly different.

That is, at the level of significance $\alpha=5 \%$ there was a statistically significant difference in the approach of public and private universities in the Czech Republic in terms of the use of individual components.

\section{CONCLUSIONS}

The aim of this paper was to identify and define the components of the missions of universities that help to build a positive ethos. Individual mission statements of all universities in the Czech 
Republic were subsequently identified and ranked. Specifically, the task was to identify following components: Education (product, service); Research; International impact; Philosophy (values and believes); Social responsibility (interest in public image); Public service; Using "we" when writing mission statement. The other goal was to analyze, whether there is different approach of public and private universities when building their missions in terms of use of above mentioned individual components.

By simply looking at the scorecard tables, it was clear that the number of the individual components contributing to building a positive mission statement ethos was more common in case of public universities, which was also confirmed by the outcomes of SPSS Statistics program. Based on the evaluation of the two-tier Student's t-test, there was accepted the alternative hypothesis: The approach to use individual components in their mission statements between public and private universities in the Czech Republic is statistically significantly different.

Concerning the use of individual components, a more pronounced difference was observed only in case of research activities and social responsibility, which are reported more frequently by public higher education institutions.

The researched findings of a lower propensity of private universities to focus more on a comprehensive and well-designed corporate statements is also aligned with a previous research of authors focusing on 214 leading private companies in the Czech Republic which showed even lower capability to formulate their mission statements. Only 33\% of companies in the sample had their mission statements (Pernica and Tyll 2016). Thus, it would be interesting to track the evolution and approach of private, profit based organizations towards this strategic message compared to their public or state-owned peers.

The topic opens up countless possibilities for further research. There would be an interesting analysis of other strategic statements in the context of the ethos of the universities. Besides missions, the attention could be paid to vision statements, ethical codes, values and more. One of the limitations of the research described above was a purely subjective assessment of the use of individual components in university missions. With this in mind, we would recommend that a larger number of evaluators should be involved in the research to objectify the results.

\section{RESOURCES}

AMATO, C. H., AMATO, L. H. Corporate commitment to quality of life: Evidence from company mission statements. 2002, Journal of Marketing Theory and Practice, roč. 10, č. 4, s. 69-87. BEASON, L. Strategies for establishing an effective persona: An analysis of appeals to ethos in business speeches. Journal of Business Communication, 1991, 28.4: 326-346.

COLLINS, J. C.; PORRAS, J. I. Organizational vision and visionary organizations. California management review, 2008, 117-137.

COOPER, By Lane. The rhetoric of Aristotle: an expanded translation with supplementary examples for students of composition and public speaking. Renewed. New Jersey: PrenticeHall, 1960. ISBN 9780137806928.

CROSS, M. Aristotle and Business Writing: Why We Need to Teach Persuasion. Bulletin of the Association for Business Communication, 1991, 54.1: 3-6.

DAVID, F. R. How companies define their mission. Long range planning. 1989, roč. 22, č. 1, s. 9097.

DRUCKER, P. F. Management: Tasks, Responsibilities, Practices. London: Heinemann, 1974. FUGAZZOTTO, S.J. Mission Statements, Physical Space, and Strategy in Higher Education, Innovative Higher Education, 2009, Vol. 34, No. 5, pp.285-298 
JONGBLOED, B., ENDERS, J., SALERNO, C. Higher education and its communities: Interconnections, interdependencies and a research agenda, Higher Education, 2008, Vol. 56, No. 3, pp.303-324.

MŠMT. Přehled vysokých škol v ČR. MŠMT [online]. 2016. [ref. 2015-11-25]. Available at: http://www.msmt.cz/vzdelavani/vysoke-skolstvi/prehled-vysokych-skol-v-cr-3

SCOTT, J. C. The Mission of the University: Medieval to Postmodern Transformations, Journal of Higher Education, 2006, Vol. 77, No.1, pp.1-39

SHANAHAN, F., SEELE, P. Shorting ethos: Exploring the relationship between aristotle's ethos and reputation management. Corporate Reputation Review, 2015, 18(1), 37-49.

STODDARD, E. W. The Role of Ethos in the Theory of Technical Writing. Technical Writing Teacher, 1984, 11.3: 229-41.

SWALES, J. M., ROGERS, P. S. Discourse and the projection of corporate culture: The mission statement. Discourse \& Society, 1995, 6.2: 223-242.

TYLL, L. Podniková strategie. 1. ed. Prague: C.H. Beck, 2014.

UNIVERZITA PALACKÉHO V OLOMOUCI. Základní informace. Univerzita Palackého $v$ Olomouci. [online]. 2016 [ref. 2016-11-25]. Available at: http://www.upol.cz/univerzita/zakladni-informace/\#c4

VYSOKÁ ŠKOLA EKONOMICKÁ V PRAZE. Profil školy. Vysoká škola ekonomická v Praze. [online]. 2016 [cit. 2016-11-25]. Available at: https://www.vse.cz/obecne/mise.php

VYSOKÁ ŠKOLA FINANČNÍ A SPRÁVNÍ. Poslání, sdílené hodnoty a vize. VŠFS. [online]. 2016 [ref. 2016-11-25]. Available at: http://www.vsfs.cz/?id=1001-univerzita

VYSOKÁ ŠKOLA PODNIKÁNÍ A PRÁVA. Výroční zpráva Vysoké školy podnikání a práva, a. s. za rok 2015. Vysoká škola podnikání a práva - VŠPP.[online]. 2016 [ref. 2016-11-25]. Available at: http://www.vspp.cz/Frontend/Webroot/uploads/files/2016/10/vyrocni_zprava_2015418.pdf

WILLIAMS, L. S. The mission statement A corporate reporting tool with a past, present, and future. Journal of Business Communication, 2008, 45.2: 94-119. 